\title{
A FRAMEWORK FOR BUYERS' HOUSE SELECTION CRITERIA VS. POST-OCCUPANCY RESIDENTIAL SATISFACTION LEVELS IN NORTH CYPRUS
}

\author{
Mehmedali EGEMEN (D) * \\ Department of Civil Engineering, Faculty of Engineering, European University of Lefke, Lefke, TR-10, \\ North Cyprus, Turkey
}

Received 04 February 2020; accepted 10 August 2020

\begin{abstract}
Intense competition existing in speculative house-building market creates an industry dominated by client groups. This paper provides insights into house-buyers' perceptions of a set of criteria contributing to their selection of the product (house) to buy together with the post-occupancy residential satisfaction levels reached after their selections, by presenting survey findings of 320 house-buyers in North Cyprus house-building market. A striking finding was the fact that the responding house-buyers belonging to different categories had very significantly different priorities in the house selection stage. Therefore, market segmentation is the area with a great potential for competitive advantage which will help the house-builders to focus on the product selection criteria of buyers in specific segments so that the capabilities and the strategies of the company can be presented in ways best suited to take advantage of these. Furthermore, the findings demonstrated that price/payment method, design and customization were all crucially important for the buyers. Therefore, builders should focus on determining the optimum customization to offer greater product choice and a proper design without losing their competitive prices. The post-occupancy residential satisfaction values varied significantly according to the categories of house-buyers. This study will combine house-buyers' product selection criteria and the related satisfaction levels reached during post-occupancy stage. Although this study was based on input provided by house-buyers in North Cyprus market, we believe the findings are of good value to builders and buyers in other similar markets.
\end{abstract}

Keywords: house-builder, house-buyer, house selection, residential satisfaction, housing, North Cyprus.

\section{Introduction}

In today's competitive markets, clients have choice since more players are competing for the same market (Egemen \& Mohamed, 2006). Achieving client satisfaction in the market has been identified as a key measure for success and an effective tool for sustaining competitive advantage (Othman, 2015). Kotler and Keller (2006) defines satisfaction as 'a person's feeling of pleasure or disappointment resulting from comparing a product's perceived performance or outcome in relation to his or her expectations. Othman (2015) discusses that client satisfaction's use as a criterion for measuring project success and gaining competitive advantage is at an early evolutionary stage in construction.

For most people, buying a house is the biggest lifetime investment. Customers and users are becoming more and more demanding, claiming for higher quality in those products which entail a major economic effort (Fernandez et al., 2016). In speculative building, house-builder purchases land, designs and constructs without reference to its customers and builds houses for selling purposes. Speculative house-builders have been traditionally criticized for poor quality, lack of customization and excessive standardization of their houses. Hofman et al. (2006) discusses that house builders in different countries are searching for ways to deliver higher levels of customization. Over the years, researchers have paid little attention to both the house-buyers' product selection and the residential satisfaction issues. There is a lack of knowledge when it comes to the way in which house-buyers make choices and what their priorities are in this selection process. The chief concern for the house-builders will be recognizing what is important to clients of different categories and presenting the capabilities of their firms in ways to meet this to best advantage. Moreover, residential satisfaction is a crucially important issue, which is not only related to a completed

${ }^{*}$ Corresponding author. E-mail: megemen@eul.edu.tr 
building but also its life cycle issue right from the initial investment stage (Jiboye, 2012). Also residential satisfaction reflects an individual's comprehensive evaluation of their housing and neighbourhood environment (Wang et al., 2019).

North Cyprus construction market is a small but a competitive market that plays a crucial role in the socio economic development of the country. According to State Planning Organization (2018), construction sector shares $5.9 \%$ of gross national product of the country and $7.0 \%$ of working population is employed in this sector. Housebuilding is a very major segment of the specified construction market. Most of the speculative housebuilders in the market offer customers a standard range of products with only a limited choice of internal details of the houses. The sector has a conservative attitude hence the emphasis assigned to innovation to improve or achieve differentiation is not high. Although the firms accept the fact that there is a need to develop a customer-focused culture, price has been the main basis for competition in the specified market.

The specified market's house-buyers' importance priority and hence behaviors in the product selection stage are not clear. Moreover, it is unknown how well the industry is meeting the customers' expectations or how satisfied the customers are in this segment. Considering the significance of the topic, a study is needed to investigate this issue thoroughly and clarify this complex picture in the specified market. This research would elicit responses from house-buyers on their perceptions of a set of criteria contributing to their selection of the house-builder and hence the house, together with the post-occupancy residential satisfaction levels reached after their selections. The findings will combine and enlighten the house-buyers' product selection criteria and the satisfaction levels reached as a result of different choices made by the buyers. Hence, an overall and complete framework including both the selection and the residential satisfaction stages of the house-buying process will be developed both for the house builders and the buyers. The findings of this study will reveal the selection and satisfaction criteria of the customers in this segment and hence provide a framework for the house builders to adopt customer-focused strategies in an effort to increase their share in the related market. Furthermore, various categories of house-buyers' possibly varying approaches to the issue will be investigated in detail.

\section{Literature review}

Numerous researchers have highlighted the importance of implementing customer-focused strategies in house-building sector. Also, many other researchers have discussed the factors affecting house-building clients' satisfaction in detail and models were proposed for measuring and improving residential satisfaction of these clients. Different surveys have been carried out to evaluate performance characteristics of builders, which contribute to clients' satisfaction.
Craig and Roy (2004) discusses the fact that UK housebuilding industry has been criticized for failing to satisfy the needs of the customers in UK and presents approaches to overcome the barriers to a customer-focused culture. Torbica and Stroh (2001) examines house- builders' performance empirically, which was measured by the degree of home buyers' satisfaction. A model was proposed, which described the house-buyer satisfaction in three dimensions, namely as house design, house quality and service. Ozaki (2003) has done an analysis of customer satisfaction concept in the service industry and identified three key aspects for housebuilding industry, which were good service, customized house design on top of quality products and good information flow. Othman (2015) aims to develop an international index for customer satisfaction in the construction industry. Zang et al. (2018) suggest that all the house-related characteristics utilized in the analysis have significantly positive effects on people's housing satisfaction, however only ownership and house size play important roles in overall happiness. Fakere et al. (2017) examined the relationship between residents' level of participation in house design and level of residential satisfaction. D. Wang and F. Wang (2016) finds out that home and neighborhood activities significantly affect residential satisfaction. Riazi and Emami (2018) carried out a study regarding affordable housing structures in Iran and planning policies, design principles and interaction with neighbors were found as the determinants of residential satisfaction. Dinc et al. (2014) determines the residential satisfaction in state mass housing projects. Nguyen et al. (2008) conducted a survey with 92 residential contractors to better understand the customer service management practices of house-builders which is very important for house-buyer satisfaction. Nahmens and Ikuma (2009) focuses on house-buyers' satisfaction with service quality and aims to assess the correlations between the factors on house-buyer expectations and their perceptions of service quality. Jiboye (2012) examined the residents' satisfaction rates, discussed the relationships between physical characteristics of the buildings and their residents' satisfaction levels. Schoenwitz et al. (2012) developed an approach to help house builders to pinpoint areas to focus efforts in providing choice to house-buyers while Fellows (2014) investigated the conceptualization of client satisfaction, in the context of determining client values and value perspectives with their aspirations for performance. Nguyen et al. (2018) examined housing satisfaction among residents living in their own affordable apartments in Vietnam and found that satisfaction was positively associated with household income but negatively related to educational levels. Residents borrowing from banks were found to be less satisfied with their homes. Additionally, respondents' positive evaluation of the features of their apartment such as the construction quality, design and the price along with the location of the house and the quality of the environment were all found to be major factors affecting housing satisfaction. Tran and Van Vu (2018) found that permanent housing and better amenities were major factors 
contributing to housing satisfaction and life satisfaction. Gender, ethnicity, employment status and education were not associated with housing satisfaction. Age was found to have an inverted U-shape relationship with housing satisfaction while better health was found to be closely linked with higher levels of housing satisfaction. The level of residential satisfaction was found to vary across the region and rural people tend to be more satisfied. Nguyen et al. (2019) examined the relationship between the access to homebuyer credits and housing satisfaction and found that access to preferential home loans has a major positive impact on housing satisfaction. The features of the houses including number of bathroom and balconies, the location of the house, its distance from school, markets were all strongly linked with housing satisfaction while the age, occupation and gender of respondents had no impact on residential satisfaction.

The findings of these studies, all provide valuable information for both the house-builders and their clients. However, a combined study providing an enhanced insight into the relationship between the house-buyers' product (house) selection criteria and the resulting postoccupancy overall satisfaction levels reached is missing. Therefore, a comprehensive study investigating the relationship between the house-buyers' product selecting criteria and their related post-occupancy overall satisfaction levels and also differentiating among various types of client groups' behaviors would be of great value.

\section{Research methodology}

In order to obtain a representative sample of house-buyers available in the market, data collection process has been made with the overall aim of maximizing the number of responding buyers. A questionnaire-based survey was employed and the research sample choice was made on the basis of representativeness and accessibility. The sample used in this study has been drawn from private housebuyers, who had bought at least one new house from a house-builder in the last 5 years to make sure that they have the relevant knowledge to answer the questionnaire accurately. Considering the fact that clients usually start to face problems after they start to live in the house, post occupancy residential satisfaction was to be measured for accurate and comprehensive evaluation. Therefore, survey respondents sample selected were all in the post occupancy period and had been living in their houses built by speculative house-builders for a minimum period of 6 months.

A two-stage sampling was used for this study, which were selection of study neighbourhood and selection of households within the selected neighbourhood. This study was conducted in three big cities, namely Nicosia, Famagusta and Kyrenia considering the fact that most of the newly built houses by the house-builders are in these three cities. For sample selection, the districts of these cities including a high number of newly built houses were listed. In Nicosia, 12 of these districts were randomly selected and in each selected district, 10 house-buyers were ran- domly selected yielding a total of 120 house-buyers. In Famagusta and Kyrenia, 10 districts were randomly selected in each city and 10 house-buyers were selected in each selected district randomly, yielding a total of 200 in these two cities. Hence the total sample for the study included 320 house-buyers in three big cities.

Although it may not be possible to list all of the factors regarding the buyers' house selection process, it was attempted to provide a very comprehensive list of factors. The previous studies regarding customer focused approaches in house-building, housing sector clients' expectations, customer preferences in housing design and housing selection, different factors contributing to post-residential satisfaction were all investigated in detail (Ozaki, 2003; Hofman et al., 2006; Nguyen et al., 2008; Schoenwitz et al., 2012; Fakere et al., 2017; Riazi \& Emami, 2018; Zang et al., 2018). In addition to combining different approaches that exist in the literature, semi-structured interviews were carried out with numerous experienced house-builders in the market regarding the factors to be included in the study. The literature review and the preliminary consultation with the experienced house-builders in the market formed the basis of the questionnaire. Before finalizing the questionnaire, semi-structured interviews were also carried out in a pilot study and the house-buyer respondents were asked to consider the clarity, representativeness, relevance and length of the questionnaire. According to the recommendations, comments and inputs obtained in the pilot study, required modifications and shortenings were incorporated to finalize the questionnaire. In order to prevent possibility of the responding clients withholding information, the anonymity of the participants in the survey was assured. A structured questionnaire was employed to assess the perceptions of house-buyers in the specified market and a total of 320 participants completed the questionnaire.

The questionnaire comprised three main sections, with many pre-determined factors listed under each of these sections. Considering the fact different categories of house-buyers' approaches to this issue can vary, different buyer categories were defined to reveal their possibly varying approaches to the specified factors in this study. The first section of the questionnaire was designed to categorize the responding house-buyers according to categories defined and requested background information about them. Section 2, which was the major section of the questionnaire, was designed to uncover the perspective of buyers regarding both the product selection process. This section was related to the criteria used by the buyers in selecting the house that they recently bought from a house-builder. The respondents were asked for their perception of importance attached to the criteria listed, while selecting the product from the house-builder. In Section 3, the respondents were asked to simply specify their overall post occupancy residential satisfaction levels reached as a result of the house chosen. The responses were analyzed separately with respect to the two specified and interrelated main sections, namely Section 2 and Section 3. 
Before interpreting the research findings, descriptive statistics about the responding house-buyers are presented in Table 1. The sample of respondents can be summarized as constituting mainly private clients, who had bought at least one new house from a speculative house-builder in the last 5 years and had lived a minimum period of 6 months in the house.

Table 1. Statistics about the characteristics of the respondents

\begin{tabular}{|l|l|l|l|}
\hline Variable & Category 1 & Category 2 & Category 3 \\
\hline $\begin{array}{l}\text { Value of the } \\
\text { product } \\
\text { (in GBP } \mathfrak{E})\end{array}$ & $\begin{array}{l}<80,000 \\
(41.56 \%)\end{array}$ & $\begin{array}{l}80,000-130,000 \\
(31.88 \%)\end{array}$ & $\begin{array}{l}130,000+ \\
(26.56 \%)\end{array}$ \\
\hline $\begin{array}{l}\text { Income level of } \\
\text { the house-buyer }\end{array}$ & $\begin{array}{l}\text { Low } \\
(17.50 \%)\end{array}$ & $\begin{array}{l}\text { Moderate } \\
(62.50 \%)\end{array}$ & $\begin{array}{l}\text { High } \\
(20.00 \%)\end{array}$ \\
\hline $\begin{array}{l}\text { Age of the house- } \\
\text { buyer }\end{array}$ & $\begin{array}{l}<40 \\
(28.44 \%)\end{array}$ & $\begin{array}{l}40-55 \\
(43.43 \%)\end{array}$ & $\begin{array}{l}55+ \\
(28.13 \%)\end{array}$ \\
\hline
\end{tabular}

The method used to analyse the data in Section 2 of the survey was the Relative Index (RI) technique that has been widely used in construction research for measuring attitude, which is the perceived level of importance in this context, with respect to surveyed variables (Shash, 1993; Kometa et al., 1994; Jennings \& Holt, 1998; Sambasivan \& Soon, 2007; Gunduz et al., 2013). The aim of the analysis was determining the relative importance of listed factors identified as factors affecting house selection and RI technique best fitted the purpose of this study. An ordinal scale was used for the measurement of variables and the respondent house-buyers were requested to assign level of importance using a five-point scale, 1 being 'very low importance', 3 being 'medium importance' and 5 being 'very high importance. Data from the questionnaires were extracted to derive RI values for each of the factors, which were rank ordered based on these values. The magnitude of RI was calculated for all the listed factors by the formula:

$$
R I=\frac{\sum W}{\left(M^{\star} N\right)},
$$

where: $W$ - weighting given to each factor by respondents (ranging from 1 to 5 ); $M$ - the maximum possible scale value ( 5 in this case); and $N$ - total no of respondents. Therefore, this yielded an RI index range from 0.2 to 1 , where 1 represented "the maximum possible importance" and 0.2 represented "the minimum possible importance".

The RI values found were used to rank different factors, which made it possible to cross-compare the relative importance of the factors as perceived by different groups of respondents.

In order to distinguish among the possible behavior variations of different categories available in house-buyer population, a collection of variables was selected that measure characteristics on which the respondent groups are expected to differ. Therefore, different subgroups in house-buyer sample were defined and analyzed separately as well. Moreover, Spearman Rank Correlation Coeffi- cient (S.R.C.C.) test was performed on the pairs of ranks, obtained for the different subgroups of house-buyers in order to define the correlation and hence the difference in behavior of varying groups of respondents regarding this issue. Spearman's Correlation Coefficient is a statistical measure of the strength of a monotonic relationship between paired data. It is a non-parametric measure of correlation based on data ranks. Unlike the most widely used Pearson's Correlation, there is no requirement of normality in S.R.C.C. This test was chosen to show the degree of agreement between the rankings considering the fact that it is a non-parametric test, which does not require the assumption of normality. Spearman's coefficient $\rho$ was calculated by using the formula:

$$
\rho=1-\frac{6 \sum d i^{2}}{n\left(n^{2}-1\right)},
$$

where: $d_{i}$ - difference between the ranks of corresponding pairs of values; $n$ - the total no of pairs of rank. The Spearman's coefficient returns a value between -1 and 1 , with 0 denoting no relationship at all. A positive correlation means both values move in the same direction, however a negative value means variables move in the opposite direction. The value +1 implies a perfect positive relationship (agreement), while -1 results from a perfect negative relationship (disagreement).

Furthermore, overall post-occupancy residential satisfaction levels reached by the responding house-buyers were analyzed in Section 3. An ordinal scale was used for the measurement of overall house-buyer satisfaction and the respondent house-buyers were requested to assign overall satisfaction score using a nine-point scale, 1 being 'the highest dissatisfaction', 5 being 'neutral case' and 9 being 'the highest satisfaction'. Data from the questionnaires were extracted and the magnitude of Overall House-Buyers' Satisfaction Score (HBS) was calculated for the respondents, which yielded an index range from 0.111 to 1 , where 1 represented 'the maximum possible satisfaction', 0.111 represented the 'maximum possible dissatisfaction' and 0.544 represented the neutral case with neither satisfaction nor dissatisfaction. HBS score was calculated by using the formula:

$$
H B S=\frac{\sum W}{\left(I^{\star} N\right)},
$$

where: $W$ - weighting given to each factor by respondents (ranging from 1 to 9 ); $I$ - the maximum possible scale value ( 9 in this case); and $N$ - total no of respondents.

\section{Research findings and discussions}

\subsection{Product selection criteria and overall satisfaction (aggregated response)}

The first part of the study focused on investigating how potential house-buyers in North Cyprus market prioritize the factors in selecting the house to buy from house-builders. Therefore, the main aim was to uncover the impor- 
tance assigned to different criteria used by the buyers in selecting the product to buy from a house-builder. The respondents were asked for their perception of importance attached to the criteria listed, while choosing the house to buy. A summary of 'Relative Indices' and Ranks derived from the responses of all of the 320 house-buyers is presented in Table 2.

The average RI value of 0.631 is quite high, which is an indication of the high emphasis assigned to the listed factors by the responding house-buyers. The extremely high importance scores of the first two factors demonstrate the crucially high importance assigned to both price and payment plan offered by the responding clients. It is a known fact that buying a house usually is the biggest lifetime investment and buyers should focus on achieving the best value. However, it is obvious that price still emerged as the leading factor in the specified market, along with the conditions of the long-term payment plan proposed by the house builder. Hence, house builders should find ways to develop products that satisfies the customers' needs without losing their competitive prices.

The factors ranked from $3^{\text {rd }}$ to $9^{\text {th }}$ were all related to the product itself or its location, but not the house-builder firm. 'The range of selection choice in interior finish details', 'the internal design and functionality of the house', 'the quality and type of the materials to be used', 'the size of indoor area', 'the external appearance of the building' and 'adequacy of daylight distribution and natural ventilation' were all factors related to the product itself and were all assigned significantly high importance scores in the selection process.

These findings definitely indicate that the house-builder firms should focus their efforts for making correct decisions about the design, size and appearance of the house at the very beginning of the process. Additionally, the fact that house-buyers appreciate the freedom of choice was also reflected in the importance scores assigned. Since prior skill and experience usually result in lower costs and probably less quality problems, standardization emerges as a primary benefit to house-builders. However, 'the range of selection choice in interior finish details' emerged as a factor with strikingly high importance score of 0.897 , while the range of selection choice in technical details and exterior details were assigned moderately high scores of 0.694 and 0.614 respectively. These findings show that house-builder firms should definitely give their clients freedom of choice, at least for interior finish details. Considering the extreme importance assigned to both 'the final price of the house' and also 'the range of selection choice in interior details', the builder firms should offer a high level customization by designing basic things in a way that would enable them to offer their clients a wide range of choices at an acceptable cost.

Considering the financial problems, late delivery and even bankruptcy of the builders encountered in the specified market in the previous years and also the fact that house-buyers sign their contracts with the house-builder firms while the product (house) is still in the design stage, one would expect that factors related to the reliability of the house-builder firm itself would be assigned high importance levels. However, the results clearly demonstrated that the factors related to the builder firm itself were assigned substantially lower importance scores, compared to the product related factors. This is an interesting finding that should be considered by the house-builder firms in the market. Among the factors related to builder firm, 'references about the house-builder', 'house-builder's previous works' quality' were selected as the two most important ones and were ranked 10th and 12th, while 'financial capacity and stability of the house-builder' was assigned a rather low importance score of 0.544 and ranked 25th. Considering these findings, it can be concluded that assuring customer satisfaction and positive word-of-mouth are crucially important and can be a market different differentiator. The builder firms should focus on strategies to completely satisfy their clients, achieve their positive recommendations and aim to do business with their friends or families in the future. On the other hand, these results also indicate that negative word-of-mouth will make it fairly difficult for a house-builder to survive in the long term in this small market. If used properly by the housebuilders, these findings may be the key to survive and beat the intense competition in this specific market.

The remaining factors related to builder-firms were assigned lower importance levels. The RI scores found for 'overall customer services and after-sales care offered' and 'warranty conditions offered' were interestingly low, indicating that the respondents did not place much emphasis on these two factors. Although after-sales care is known to be important for customers' satisfaction in the post occupancy stage, the findings indicate that buyers do not assign high emphasis to this factor in the product-selection stage. However, caring for customers and providing them the service required in the post-occupancy stage is still rather important since it may be one of the critical keys to increase satisfaction of customers and gain advantage strategically in future works with positive-word-of-mouth.

The 'advertisements of the project' and 'the documents provided by the builder firm' did not come out as very major factors in the selection process while the 'the builder firm's overall communication with the client' and 'image and identity of the builder firm' received considerably higher importance scores. These findings indicate that house-builders should focus on communicating effectively with their clients and building an overall strong firm image in the market.

As a result of the priorities or importance values assigned to different factors in the product selection stage, a house was selected and bought by each of the 320 respondents. Overall House-Buyers' Satisfaction Score (HBS) would measure overall post-occupancy residential satisfaction levels reached by these house-buyers as a result of the product they selected. The Overall House-Buyers' Satisfaction Score (HBS) was found as 0.505 , as presented in Table 2. The score of 0.505 , which is far less than the maximum possible satisfaction score of 1 and even less 
than the neutral case value 0.544 , indicates a significant dissatisfaction of the responding buyers with the houses they bought. In today's competitive markets, achieving house-buyers' satisfaction is a key measure for success and satisfied customers are the backbone of the house-building industry. Actually, positive word-of-mouth traditionally has been significantly important in house-building market of North Cyprus. The findings of this study also reveals that among the factors related to builder firm itself, 'references about house-builder', was selected as the most important factor by the respondents in selecting the house to buy from a house-builder. There is a strong correlation between clients' satisfaction and their willingness to recommend the firm to their friends or families. Therefore, house-builders should focus their efforts in determining and applying appropriate customer-focused strategies, in an effort to increase overall customer satisfaction. Actually, this strikingly low overall satisfaction level indicates that in this highly competitive market, there is room for improvement of builders in being more customer-focused.

Table 2. Product selection criteria and satisfaction level (aggregated response)

\begin{tabular}{|c|c|c|c|}
\hline $\mathrm{N}$ & Factor description & RI & Rank \\
\hline 1 & The final price of the house & 0.942 & 1 \\
\hline 2 & The payment plan proposed by the house-builder (duration, interest rate, etc.) & 0.928 & 2 \\
\hline 3 & The range of selection choice in interior finish details & 0.897 & 3 \\
\hline 4 & The internal design and functionality of the house & 0.893 & 4 \\
\hline 5 & The quality and type of the materials to be used & 0.873 & 5 \\
\hline 6 & The size of indoor area & 0.866 & 6 \\
\hline 7 & The convenience of estate location (i.e. distance to the city/town center) & 0.841 & 7 \\
\hline 8 & The external appearance of the building & 0.800 & 8 \\
\hline 9 & Adequacy of daylight distribution and natural ventilation & 0.778 & 9 \\
\hline 10 & References about the house-builder & 0.759 & 10 \\
\hline 11 & Legal status of the land of the house & 0.706 & 11 \\
\hline 12 & House-builder's previous works' quality & 0.703 & 12 \\
\hline 13 & The range of selection choice in technical details of the house & 0.694 & 13 \\
\hline 14 & Current stage of construction/time of delivery & 0.690 & 14 \\
\hline 15 & Adequacy of outdoor/garden/landscaping areas & 0.669 & 15 \\
\hline 16 & The image and identity of the builder firm in the market & 0.637 & 16 \\
\hline 17 & The builder firm's overall communication with the client & 0.618 & 17 \\
\hline 18 & The range of selection choice in exterior details of the house & 0.614 & 18 \\
\hline 19 & Experience of the house-builder (no. of years in the market) & 0.603 & 19 \\
\hline 20 & Overall contract conditions & 0.600 & 20 \\
\hline 21 & Overall customer services and after-sales care offered & 0.573 & 21 \\
\hline 22 & Safety and security of the house's neighbourhood & 0.567 & 22 \\
\hline 23 & Warranty conditions the builder firm offered & 0.550 & 23 \\
\hline 24 & Urban aesthetics in the neighbourhood area & 0.547 & 24 \\
\hline 25 & Financial capacity and stability of the house-builder & 0.544 & 25 \\
\hline 26 & Adequacy of privacy from neighbors & 0.481 & 26 \\
\hline 27 & Social/recreation centers in the near neighbourhood & 0.479 & 27 \\
\hline 28 & Expected land value increase in the neighbourhood area & 0.470 & 28 \\
\hline 29 & Advertisements of the project & 0.464 & 29 \\
\hline 30 & Isolation/heating systems of the house (thermal comfort) & 0.429 & 30 \\
\hline 31 & Risks available due to inflation rate or instability of currency exchange rates & 0.424 & 31 \\
\hline 32 & Availability of technical ability and resources of the builder & 0.375 & 32 \\
\hline 33 & The documents provided by the builder firm during the first visit & 0.364 & 33 \\
\hline 34 & Builder-firm' managerial capacity with similar size previous projects & 0.359 & 34 \\
\hline \multirow[t]{3}{*}{35} & Previous records of claims and disputes about the builder & 0.357 & 35 \\
\hline & Average RI: & 0.631 & \\
\hline & Overall house-buyers' satisfaction (HBS): & 0.505 & \\
\hline
\end{tabular}




\subsection{Product selection criteria and satisfaction (subgroups)}

In addition to overall responding house-buyers' results, the importance scores for many different subgroups available in our respondents' sample are presented in Tables 3,4 and 5 to provide the insight of different house-buyer groups' expectations. The factors with low importance scores were discarded and the top-twenty factors were used for correlation tests among different subgroups.

The overall observation of the results in Table 3 confirms that there is a distinct and significant variation of scores among the groups of respondents categorized according to various control variables. Although obvious differences exist among factor rankings of the three specified categories, the S.R.C.C. test showed a strong correlation to exist in each case. The least correlation existed between Groups 1 and $3\left(r_{s}=0.75\right)$, while higher correlation existed between Groups 1 and $2\left(r_{s}=0.87\right)$ and 2 and $3\left(r_{s}=0.94\right)$. Actually, these findings clearly reveal that there is an important increase in correlation among subgroups having smaller differences in project values. The house-buyers' importance priority varied when there is a high difference in project values. On the other hand, the buyers involved in projects of similar values had more similar priorities. This is an interesting finding that should be assigned enough emphasis, considering the fact that there exist many house-builder firms in the market, which specialize on certain types or sizes of projects. This is the area with a potential for competitive advantage, which may lead to a path to increase their market share. Hence, the house-builders should do market segmentation and focus on the details of selection criteria and satisfaction levels of the buyers in the related specific categories.

When the factors are investigated in detail, it is apparent that 'the final price of the house' is the leading factor in all three subgroups, as expected. Also, it can be observed that Group 1 buyers assigned more emphasis on the payment plan proposed by the house-builder' and 'the size of indoor area' while Groups 2 and 3 respondents assigned higher rankings to 'the range of selection choice in interior finish details', 'the quality and type of the materials to be used', 'the external appearance of the building' and 'the range of selection choice in exterior details. These findings reveal the significance of freedom of choice, quality and aesthetic appearance, especially for house-builders whose target markets consist of higher value projects' buyers. On the other hand, budgets of Group 1 buyers may be limited and the builders targeting lower value projects' buyers should focus on determining the optimum size of house with a competitive price and an advantageous payment plan.

Of specific interest, both 'current stage of construction/time of delivery' and 'experience of the house-builder' seem to be more important for smaller value project buyers while 'adequacy of outdoor/garden/landscaping areas', 'the image and identity of the builder firm in the market' and 'references about the house-builder' are more important for higher value projects buyers. Although importance values for 'financial capacity and stability of the house-builder' were low for all categories, that Group 1 buyers assigned slightly more significance to this specific factor.

When the House-Buyers' satisfaction scores are investigated, the post-occupancy overall residential satisfaction levels reached by all three of these subgroups seemed to be low. The findings indicate that Group 2 respondents are more satisfied than the respondents in other categories as presented in Table 3. The score of 0.546 for Group 2 is just above the neutral value while the scores for other groups are much lower than the neutral value indicating a fairly significant dissatisfaction of the responding buyers with the houses they bought. The lowest satisfaction score is found for the respondents in the lowest product value category $(\mathrm{HBS}=0.465)$. The buyers in this category, who assigned more significance on optimum size of house, competitive price and advantageous payment plan, were the most dissatisfied group. On the other hand, Group 2 and Group 3 respondents, who assigned more emphasis on freedom of choice, quality and aesthetic appearance, were less dissatisfied. The strikingly low satisfaction level for Group 1 respondents indicates that there is room for improvement of house-builders specifically for lower value projects segment of the market. Therefore, house-builders should differentiate themselves from the others, analyze potential customers' requirements in this segment and apply customer-focused strategies to gain competitive advantage.

For only the selected factors which had striking findings in the comparisons, rank variations are displayed in Figure 1. Selected factors' ID numbers ('N' in Table 1) are displayed on the $\mathrm{X}$-axis, their respective ranks are shown on the $y$-axis while the different categories are displayed in different colours. Moreover, seven highest ranked factors for each category of the value of the product are displayed in Figure 2. RI index for each factor is displayed on y-axis, ID numbers of the factors are displayed on top of the coloured columns while the different ranks from 1 to 7 are displayed in different colours.

The results in Table 4 showed the approaches of different groups of house-buyers categorized by their income levels. The S.R.C.C. test revealed that the least correlation existed between Groups 1 and $3\left(r_{s}=0.83\right)$, while very high correlation existed between Groups 1 and $2\left(r_{s}=0.94\right)$ and 2 and 3 (0.95). These findings reveal that there is an important increase in correlation among subgroups having smaller differences in income levels. The house-buyers' importance priority varied when the difference in income levels increased. Hence, the builders should focus on the details of selection criteria and satisfaction levels of the specific buyer groups who are within their target segment.

When the differences among the categories are investigated in detail, it is observed that clients with high income level assigned a lower rank on 'the payment plan proposed by the house-builder' compared to the other two groups. Actually, the fact that high income level buyers may not assign extreme significance to long term payment plans offered is expected. Buyers with low income levels assigned more emphasis on 'the size of indoor area' and 
Table 3. Product selection criteria and satisfaction by the value of the product ${ }^{\mathrm{a}}$

\begin{tabular}{|c|c|c|c|c|c|c|c|}
\hline \multirow{2}{*}{\multicolumn{2}{|c|}{ Value of product $(\mathfrak{E})$}} & \multirow{2}{*}{\multicolumn{2}{|c|}{$\frac{<80,000}{(\text { Group 1) }}$}} & \multirow{2}{*}{\multicolumn{2}{|c|}{$\frac{80,000-130,000}{(\text { Group 2) }}$}} & \multirow{2}{*}{\multicolumn{2}{|c|}{$\frac{130,000+}{\text { (Group 3) }}$}} \\
\hline & & & & & & & \\
\hline $\mathrm{N}$ & Factor description & RI & Rank & RI & Rank & RI & Rank \\
\hline 1 & The final price of the house & 0.948 & 1 & 0.943 & 1 & 0.932 & 1 \\
\hline 2 & $\begin{array}{l}\text { The payment plan proposed by the house-builder (duration, interest } \\
\text { rate, etc.) }\end{array}$ & 0.943 & 2 & 0.934 & 3 & 0.899 & 4 \\
\hline 3 & The range of selection choice in interior finish details & 0.852 & 4 & 0.938 & 2 & 0.919 & 2 \\
\hline 4 & The internal design and functionality of the house & 0.895 & 3 & 0.901 & 4 & 0.882 & 5 \\
\hline 5 & The quality and type of the materials to be used & 0.826 & 7 & 0.898 & 5 & 0.916 & 3 \\
\hline 6 & The size of indoor area & 0.850 & 5 & 0.881 & 7 & 0.872 & 7 \\
\hline 7 & $\begin{array}{l}\text { The convenience of estate location (i.e. distance to the city/town } \\
\text { centre) }\end{array}$ & 0.837 & 6 & 0.883 & 6 & 0.841 & 8 \\
\hline 8 & The external appearance of the building & 0.712 & 13 & 0.849 & 8 & 0.879 & 6 \\
\hline 9 & Adequacy of daylight distribution and natural ventilation & 0.806 & 8 & 0.759 & 10 & 0.760 & 10 \\
\hline 10 & References about the house-builder & 0.723 & 11 & 0.805 & 9 & 0.761 & 9 \\
\hline 11 & Legal status of the land of the house & 0.722 & 12 & 0.702 & 12 & 0.685 & 13 \\
\hline 12 & House-builder's previous works' quality & 0.688 & 14 & 0.723 & 11 & 0.701 & 12 \\
\hline 13 & The range of selection choice in technical details of the house & 0.729 & 10 & 0.659 & 15 & 0.681 & 14 \\
\hline 14 & Current stage of construction/time of delivery & 0.756 & 9 & 0.695 & 13 & 0.583 & 18 \\
\hline 15 & Adequacy of outdoor/garden/landscaping areas & 0.600 & 18 & 0.690 & 14 & 0.752 & 11 \\
\hline 16 & The image and identity of the builder firm in the market & 0.595 & 20 & 0.656 & 16 & 0.678 & 15 \\
\hline 17 & The builder firm's overall communication with the client & 0.632 & 16 & 0.615 & 19 & 0.599 & 17 \\
\hline 18 & The range of selection choice in exterior details of the house & 0.590 & 21 & 0.616 & 18 & 0.650 & 16 \\
\hline 19 & Experience of the house-builder (no. of years in the market) & 0.667 & 15 & $0.556+$ & 20 & 0.560 & 19.5 \\
\hline 20 & Overall contract conditions & 0.614 & 17 & 0.620 & 17 & 0.557 & 21 \\
\hline 21 & Overall customer services and after-sales care offered & 0.599 & 19 & 0.552 & 22 & 0.555 & 22 \\
\hline 22 & Safety and security of the house's neighbourhood & 0.583 & 25 & 0.554 & 21 & 0.560 & 19.5 \\
\hline 23 & Warranty conditions the builder firm offered & 0.586 & 23 & 0.529 & 24 & 0.520 & 24.5 \\
\hline 24 & Urban aesthetics in the neighbourhood area & 0.584 & 24 & 0.523 & 25 & 0.520 & 24.5 \\
\hline 25 & Financial capacity and stability of the house-builder & 0.589 & 22 & 0.515 & 27 & 0.510 & 27 \\
\hline 26 & Adequacy of privacy from neighbors & 0.417 & 29 & 0.5311 & 23 & 0.523 & 23 \\
\hline 27 & Social/recreation centers in the near neighbourhood & 0.488 & 27 & 0.471 & 28 & 0.476 & 28 \\
\hline 28 & Expected land value increase in the neighbourhood area & 0.489 & 26 & 0.519 & 26 & 0.421 & 29 \\
\hline 29 & Advertisements of the project & 0.429 & 28 & 0.469 & 29.5 & 0.511 & 26 \\
\hline 30 & Isolation/heating systems of the house (thermal comfort) & 0.407 & 31 & 0.466 & 31 & 0.420 & 30 \\
\hline 31 & $\begin{array}{l}\text { Risks available due to inflation rate or instability of currency } \\
\text { exchange rates }\end{array}$ & 0.415 & 30 & 0.469 & 29.5 & 0.385 & 34 \\
\hline 32 & Availability of technical ability and resources of the builder & 0.352 & 32 & 0.392 & 32 & 0.390 & 32 \\
\hline 33 & The documents provided by the builder firm during the first visit & 0.349 & 34 & 0.362 & 33 & 0.388 & 33 \\
\hline 34 & Builder-firm' managerial capacity with similar size previous projects & 0.350 & 33 & 0.337 & 35 & 0.401 & 31 \\
\hline 35 & Previous records of claims and disputes about the builder & 0.348 & 35 & 0.359 & 34 & 0.368 & 35 \\
\hline & Average RI: & 0.628 & & 0.639 & & 0.630 & \\
\hline & Overall house-buyers' satisfaction (HBS): & 0.465 & & 0.546 & & 0.520 & \\
\hline
\end{tabular}




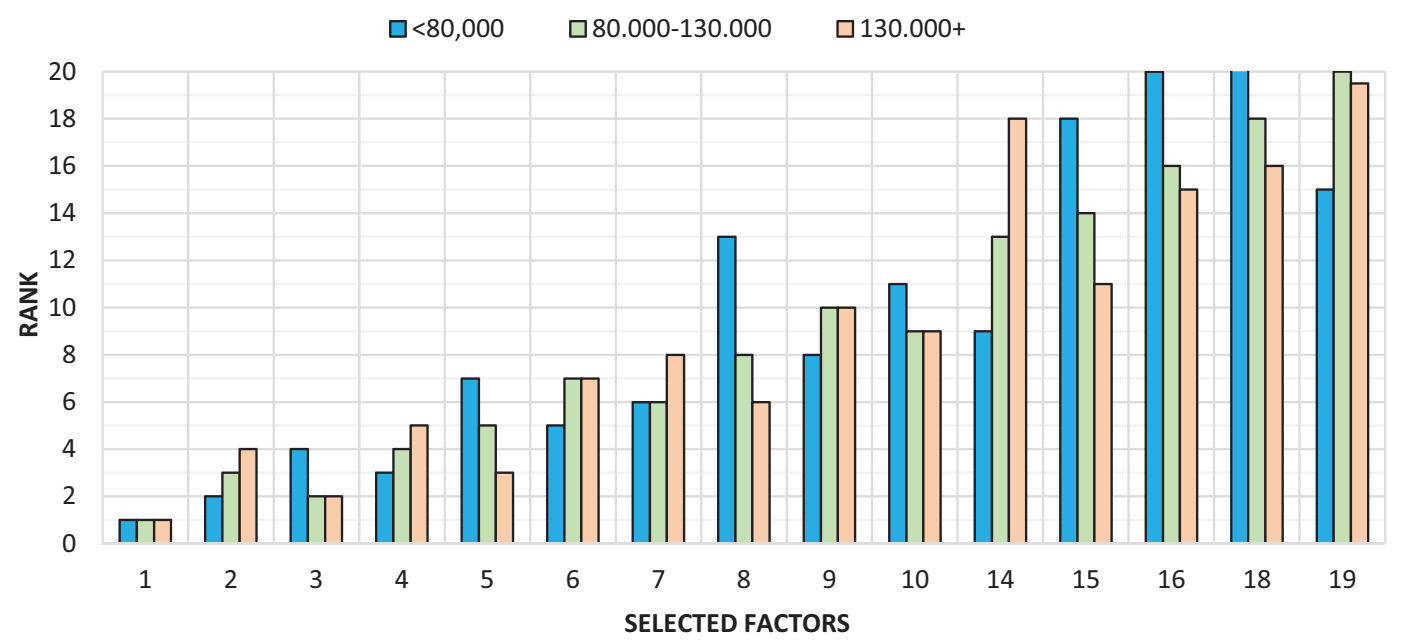

Figure 1. Rank variations by the value of the product in $£$

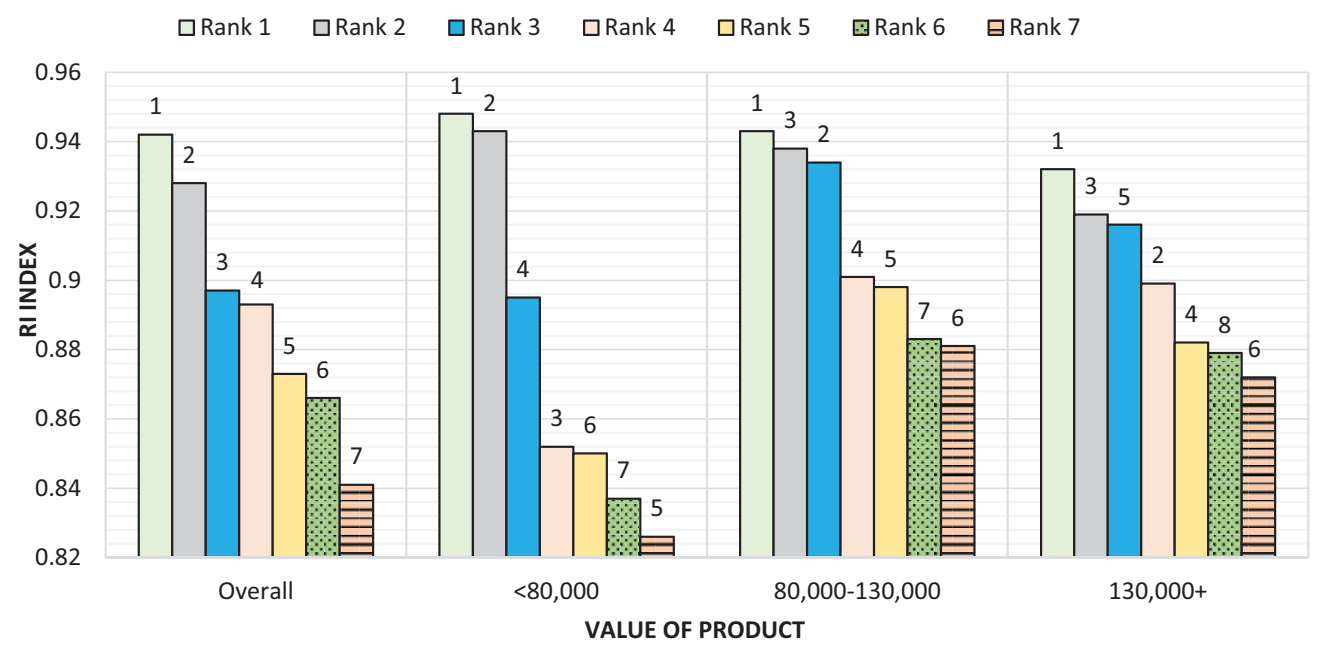

Figure 2. Seven highest ranked factors for each category of the value of the product

'adequacy of daylight distribution and natural ventilation. The emphasis assigned to the factors 'the range of selection choice in interior finish details', 'the quality and type of the materials to be used', 'the external appearance of the building' and 'the range of selection choice in exterior details' increased significantly with increasing income levels. These findings actually uncover the importance of freedom of choice, quality and aesthetic appearance, especially for the house-builders whose target market consists of buyers with higher income levels. The rankings assigned to the factors 'image and identity of the builder firm in the market' and 'house-builder's previous works' quality' increased with increasing income levels. This is a clear indication for the need of building a strong firm image with a successful firm history, especially for builders who target higher income level clients market. On the other hand, the emphasis for 'current stage of construction/time of delivery' increased with decreasing income level. This may be an indication of these respondents' urgent need for a house or it may be explained by their need to invest their money in a more secure option, considering the fact that investing money for a house long before the construction stage can be risky. Although importance scores for 'Over- all contract conditions' and 'Overall customer services and after-sales care offered' were moderately low for all three groups, low income level buyers assigned slightly higher ranks to these factors. This may be an indication that buyers with limited budgets are looking for more secure options. Of specific interest, 'adequacy of outdoor/garden/ landscaping seem to be more important for buyers with high income level.

The House-Buyers' Satisfaction Scores presented in Table 4 reveal that the post-occupancy overall residential satisfaction levels are lower than the neutral value indicating a fairly significant dissatisfaction of the responding buyers regardless of their category. However, it is interesting that moderate level income buyers have less dissatisfaction than the other two groups as presented in Table 4 . The HBS score of 0.520 for moderate level income buyers is quite higher than the scores found for the other two groups. The satisfaction scores found for the respondents with high and low income levels were 0.477 and 0.480 respectively. The significantly low satisfaction levels for Group 1 and Group 3 respondents reveals that, there is room for improvement of house-builders specifically for low and high income level clients segment of the market. 
Table 4. Product selection criteria and satisfaction by the income level of the house-buyer ${ }^{\mathrm{a}}$

\begin{tabular}{|c|c|c|c|c|c|c|c|}
\hline \multirow{2}{*}{\multicolumn{2}{|c|}{ Income level of the house-buyer }} & \multirow{2}{*}{\multicolumn{2}{|c|}{$\frac{\text { Low }}{\text { (Group 1) }}$}} & \multirow{2}{*}{\multicolumn{2}{|c|}{$\begin{array}{l}\text { Moderate } \\
\text { (Group 2) }\end{array}$}} & \multirow{2}{*}{\multicolumn{2}{|c|}{$\frac{\text { High }}{\text { (Group 3) }}$}} \\
\hline & & & & & & & \\
\hline $\mathrm{N}$ & Factor description & RI & Rank & RI & Rank & RI & Rank \\
\hline 1 & The final price of the house & 0.955 & 1 & 0.944 & 1 & 0.922 & 1 \\
\hline 2 & $\begin{array}{l}\text { The payment plan proposed by the house-builder (duration, } \\
\text { interest rate, etc.) }\end{array}$ & 0.947 & 2 & 0.938 & 2 & 0.877 & 5 \\
\hline 3 & The range of selection choice in interior finish details & 0.868 & 5 & 0.899 & 3 & 0.917 & 2 \\
\hline 4 & The internal design and functionality of the house & 0.908 & 3 & 0.890 & 4 & 0.887 & 4 \\
\hline 5 & The quality and type of the materials to be used & 0.828 & 7 & 0.879 & 5 & 0.895 & 3 \\
\hline 6 & The size of indoor area & 0.870 & 4 & 0.868 & 6 & 0.856 & 7 \\
\hline 7 & $\begin{array}{l}\text { The convenience of estate location (i.e. distance to the city/town } \\
\text { cente) }\end{array}$ & 0.830 & 6 & 0.850 & 7 & 0.822 & 8 \\
\hline 8 & The external appearance of the building & 0.702 & 11 & 0.806 & 8 & 0.869 & 6 \\
\hline 9 & Adequacy of daylight distribution and natural ventilation & 0.810 & 8 & 0.785 & 9 & 0.727 & 11 \\
\hline 10 & References about the house-builder & 0.783 & 9 & 0.749 & 10 & 0.771 & 9 \\
\hline 11 & Legal status of the land of the house & 0.695 & 12 & 0.713 & 11 & 0.695 & 13.5 \\
\hline 12 & House-builder's previous works' quality & 0.658 & 14 & 0.698 & 12 & 0.758 & 10 \\
\hline 13 & The range of selection choice in technical details of the house & 0.694 & 13 & 0.693 & 14 & 0.695 & 13.5 \\
\hline 14 & Current stage of construction/time of delivery & 0.755 & 10 & 0.695 & 13 & 0.611 & 17 \\
\hline 15 & Adequacy of outdoor/garden/landscaping areas & 0.652 & 15 & 0.665 & 15 & 0.696 & 12 \\
\hline 16 & The image and identity of the builder firm in the market & 0.588 & 20 & 0.640 & 16 & 0.674 & 15 \\
\hline 17 & The builder firm's overall communication with the client & 0.635 & 16 & 0.622 & 17 & 0.590 & 18.5 \\
\hline 18 & The range of selection choice in exterior details of the house & 0.563 & 21 & 0.613 & 18 & 0.665 & 16 \\
\hline 19 & Experience of the house-builder (no. of years in the market) & 0.633 & 17.5 & 0.598 & 19 & 0.590 & 18.5 \\
\hline 20 & Overall contract conditions & 0.633 & 17.5 & 0.597 & 20 & 0.578 & 21 \\
\hline 21 & Overall customer services and after-sales care offered & 0.590 & 19 & 0.572 & 22 & 0.562 & 22 \\
\hline 22 & Safety and security of the house's neighbourhood & 0.484 & 26 & 0.586 & 21 & 0.579 & 20 \\
\hline 23 & Warranty conditions the builder firm offered & 0.559 & 22 & 0.551 & 24 & 0.538 & 25 \\
\hline 24 & Urban aesthetics in the neighbourhood area & 0.535 & 24 & 0.552 & 23 & 0.543 & 24 \\
\hline 25 & Financial capacity and stability of the house-builder & 0.558 & 23 & 0.543 & 25 & 0.534 & 26 \\
\hline 26 & Adequacy of privacy from neighbors & 0.430 & 29 & 0.475 & 27 & 0.544 & 23 \\
\hline 27 & Social/recreation centers in the near neighbourhood & 0.509 & 25 & 0.480 & 26 & 0.450 & 29 \\
\hline 28 & Expected land value increase in the neighbourhood area & 0.490 & 27 & 0.470 & 28 & 0.459 & 28 \\
\hline 29 & Advertisements of the project & 0.469 & 28 & 0.454 & 29 & 0.494 & 27 \\
\hline 30 & Isolation/heating systems of the house (thermal comfort) & 0.420 & 30.5 & 0.430 & 31 & 0.435 & 30 \\
\hline 31 & $\begin{array}{l}\text { Risks available due to inflation rate or instability of currency } \\
\text { exchange rates }\end{array}$ & 0.420 & 30.5 & 0.440 & 30 & 0.376 & 34 \\
\hline 32 & Availability of technical ability and resources of the builder & 0.378 & 32 & 0.3700 & 32 & 0.386 & 32 \\
\hline 33 & The documents provided by the builder firm during the first visit & 0.366 & 33 & 0.356 & 33 & 0.390 & 31 \\
\hline 34 & $\begin{array}{l}\text { Builder-firm' managerial capacity with similar size previous } \\
\text { projects }\end{array}$ & 0.359 & 34 & 0.354 & 34 & 0.377 & 33 \\
\hline 35 & Previous records of claims and disputes about the builder & 0.357 & 35 & 0.353 & 35 & 0.372 & 35 \\
\hline & Average RI: & 0.627 & & 0.632 & & 0.632 & \\
\hline & Overall house-buyers' satisfaction (HBS): & 0.480 & & 0.520 & & 0.477 & \\
\hline
\end{tabular}

Note: ${ }^{\text {a }}$ Spearman Rank Correlation Coefficient $\left(\mathrm{r}_{\mathrm{s}}\right)$ between groups 1 and $2=0.94 ; 1$ and $3=0.83 ; 2$ and $3=0.95$; correlation is significant at $1 \%$ level for all. 


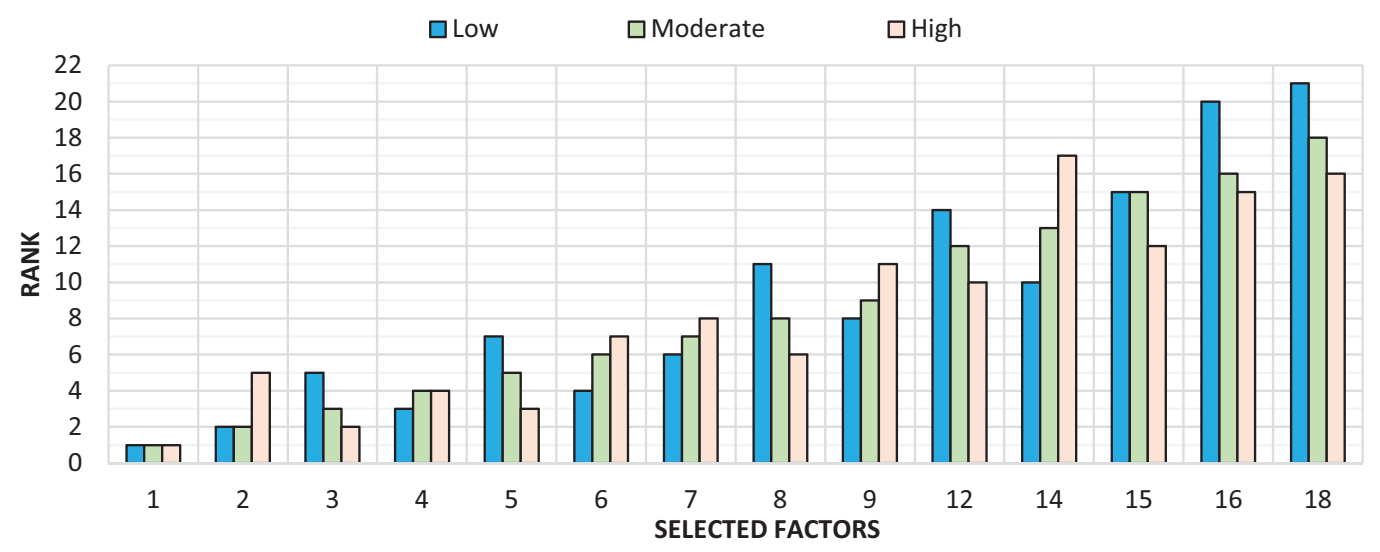

Figure 3. Rank variations by the income level of the house-buyer

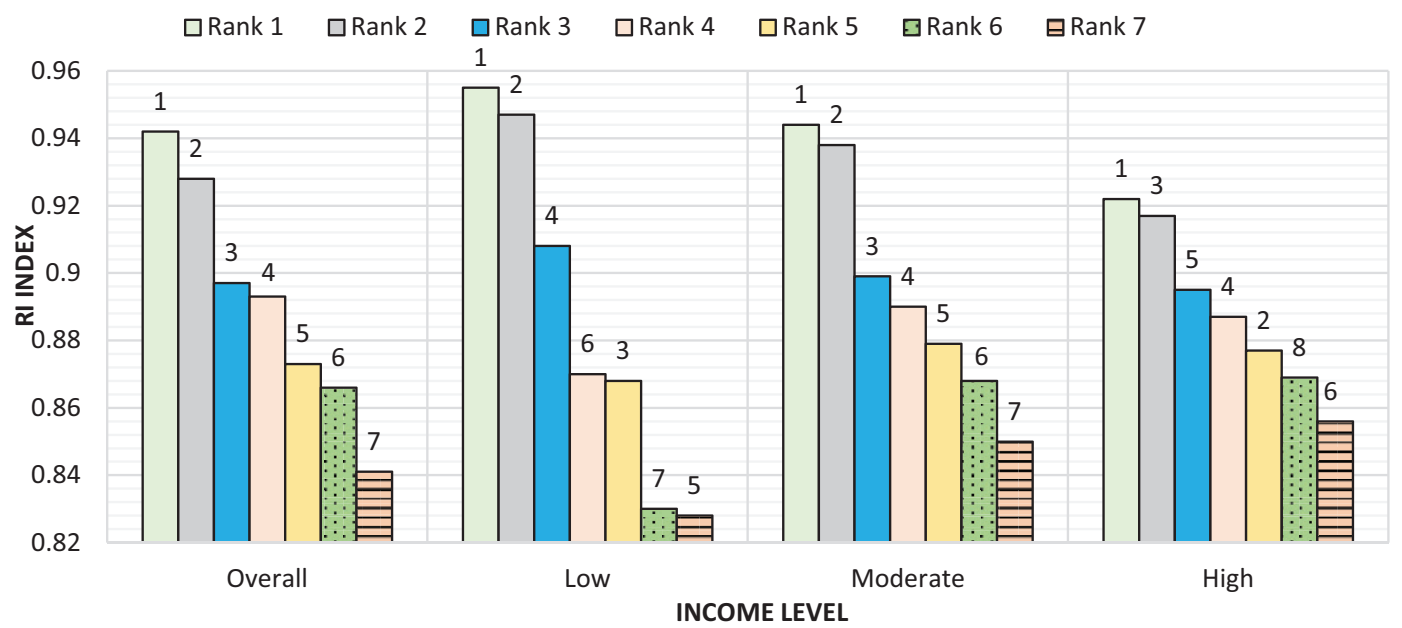

Figure 4. Seven highest ranked factors for each category of the income level of the house-buyer

For only the selected factors which had striking findings in the comparisons in this category, rank variations are displayed in Figure 3. Selected factors' ID numbers are displayed on the $\mathrm{X}$-axis, their respective ranks are shown on the $y$-axis while the different categories are displayed in different colours. Moreover, seven highest ranked factors for each category of the income level of the house buyer are displayed in Figure 4. RI index for each factor is displayed on y-axis, ID numbers of the factors are displayed on top of the coloured columns while the different ranks from 1 to 7 are displayed in different colours.

The observation of the findings presented in Table 5 clearly demonstrates the varying approaches of different groups of house-buyers categorized by age. Although obvious and important differences are observed among factor rankings of the three different categories, the S.R.C.C. test showed a fairly strong correlation to exist in each case. The least correlation existed between Groups 1 and $3\left(\mathrm{r}_{\mathrm{s}}=\right.$ $0.77)$, while higher correlation existed between Groups 1 and $2\left(r_{s}=0.94\right)$ and 2 and $3(0.83)$. These findings showed that the house-buyers' behavior in product selection varied more with increasing difference in age groups of the responding buyers. On the other hand, the buyers belonging to similar age groups had more similar importance priorities.
The analysis of the factors in detail reveals that there is an obvious and significant increase in importance assigned to 'the range of selection choice in interior finish details', 'the range of selection choice in technical details of the house' and 'the external appearance of the building' with decreasing age of the respondents. These findings uncover the significance of 'freedom of choice' and 'aesthetic external appearance', especially for house-builders whose target market consists of young or middle-aged buyers. The results also demonstrated that 'the internal design and functionality of the house,' 'the convenience of estate location', 'adequacy of outdoor/garden/landscaping areas' and 'references about the house-builder' were assigned significantly more emphasis by higher age respondents. Therefore, the builders targeting older age groups should focus on internal design, functionality, location and outdoor area of the house. Of specific interest, Group 3 respondents also assigned significantly higher ranks to 'overall customer services and after-sales care offered' and 'safety and security of the house's neighbourhood' compared to the other two age groups.

The factor 'experience of the house-builder' was assigned strikingly more importance by higher age groups while the image and identity of the builder firm in the 
Table 5. Product selection criteria and satisfaction by the age of the house-buyer ${ }^{\text {a }}$

\begin{tabular}{|c|c|c|c|c|c|c|c|}
\hline \multirow{2}{*}{\multicolumn{2}{|c|}{ Age of the house-buyer }} & \multicolumn{2}{|c|}{$<40$} & \multicolumn{2}{|c|}{$40-55$} & \multicolumn{2}{|c|}{$55+$} \\
\hline & & \multicolumn{2}{|c|}{ (Group 1) } & \multicolumn{2}{|c|}{ (Group 2) } & \multicolumn{2}{|c|}{ (Group 3) } \\
\hline $\mathrm{N}$ & Factor description & RI & Rank & RI & Rank & RI & Rank \\
\hline 1 & The final price of the house & 0.950 & 1 & 0.940 & 1 & 0.938 & 1 \\
\hline 2 & $\begin{array}{l}\text { The payment plan proposed by the house-builder (duration, } \\
\text { interest rate, etc.) }\end{array}$ & 0.926 & 3 & 0.934 & 2 & 0.920 & 3 \\
\hline 3 & The range of selection choice in interior finish details & 0.935 & 2 & 0.904 & 3 & 0.846 & 7 \\
\hline 4 & The internal design and functionality of the house & 0.892 & 4 & 0.869 & 6 & 0.930 & 2 \\
\hline 5 & The quality and type of the materials to be used & 0.872 & 5 & 0.874 & 5 & 0.874 & 5.5 \\
\hline 6 & The size of indoor area & 0.859 & 7 & 0.899 & 4 & 0.821 & 8 \\
\hline 7 & $\begin{array}{l}\text { The convenience of estate location (i.e. distance to the city/town } \\
\text { cente) }\end{array}$ & 0.815 & 8 & 0.836 & 7 & 0.874 & 5.5 \\
\hline 8 & The external appearance of the building & 0.861 & 6 & 0.792 & 8 & 0.749 & 10 \\
\hline 9 & Adequacy of daylight distribution and natural ventilation & 0.726 & 10.5 & 0.750 & 9 & 0.875 & 4 \\
\hline 10 & References about the house-builder & 0.720 & 12 & 0.745 & 10 & 0.819 & 9 \\
\hline 11 & Legal status of the land of the house & 0.690 & 13 & 0.724 & 11 & 0.695 & 12.5 \\
\hline 12 & House-builder's previous works' quality & 0.683 & 14 & 0.721 & 12 & 0.695 & 12.5 \\
\hline 13 & The range of selection choice in technical details of the house & 0.726 & 10.5 & 0.709 & 13 & 0.638 & 18 \\
\hline 14 & Current stage of construction/time of delivery & 0.750 & 9 & 0.669 & 14 & 0.661 & 15 \\
\hline 15 & Adequacy of outdoor/garden/landscaping areas & 0.612 & 16.5 & 0.661 & 15 & 0.740 & 11 \\
\hline 16 & The image and identity of the builder firm in the market & 0.678 & 15 & 0.640 & 16.5 & 0.590 & 20 \\
\hline 17 & The builder firm's overall communication with the client & 0.612 & 16.5 & 0.637 & 18.5 & 0.596 & 19 \\
\hline 18 & The range of selection choice in exterior details of the house & 0.611 & 18 & 0.640 & 16.5 & 0.576 & 22 \\
\hline 19 & Experience of the house-builder (no. of years in the market) & 0.572 & 19 & 0.570 & 20 & 0.686 & 14 \\
\hline 20 & Overall contract conditions & 0.568 & 21 & 0.637 & 18.5 & 0.575 & 23 \\
\hline 21 & Overall customer services and after-sales care offered & 0.553 & 22 & 0.536 & 23 & 0.650 & 16 \\
\hline 22 & Safety and security of the house's neighbourhood & 0.540 & 24 & 0.532 & 25 & 0.642 & 17 \\
\hline 23 & Warranty conditions the builder firm offered & 0.569 & 20 & 0.546 & 22 & 0.536 & 25 \\
\hline 24 & Urban aesthetics in the neighbourhood area & 0.500 & 26 & 0.556 & 21 & 0.579 & 21 \\
\hline 25 & Financial capacity and stability of the house-builder & 0.535 & 25 & 0.533 & 24 & 0.572 & 24 \\
\hline 26 & Adequacy of privacy from neighbors & 0.541 & 23 & 0.476 & 27 & 0.429 & 28 \\
\hline 27 & Social/recreation centers in the near neighbourhood & 0.487 & 27 & 0.456 & 29 & 0.506 & 26 \\
\hline 28 & Expected land value increase in the neighbourhood area & 0.462 & 29 & 0.504 & 26 & 0.424 & 31 \\
\hline 29 & Advertisements of the project & 0.483 & 28 & 0.475 & 28 & 0.428 & 29 \\
\hline 30 & Isolation/heating systems of the house (thermal comfort) & 0.420 & 30 & 0.398 & 31 & 0.485 & 27 \\
\hline 31 & $\begin{array}{l}\text { Risks available due to inflation rate or instability of currency } \\
\text { exchange rates }\end{array}$ & 0.411 & 31 & 0.432 & 30 & 0.425 & 30 \\
\hline 32 & Availability of technical ability and resources of the builder & 0.384 & 32 & 0.381 & 32 & 0.357 & 34 \\
\hline 33 & The documents provided by the builder firm during the first visit & 0.358 & 33.5 & 0.359 & 33 & 0.377 & 32 \\
\hline 34 & $\begin{array}{l}\text { Builder-firm' managerial capacity with similar size previous } \\
\text { projects }\end{array}$ & 0.358 & 33.5 & 0.357 & 34 & 0.363 & 33 \\
\hline 35 & Previous records of claims and disputes about the builder & 0.356 & 35 & 0.354 & 35 & 0.362 & 35 \\
\hline & Average RI: & 0.629 & & 0.628 & & 0.630 & \\
\hline & Overall house-buyers' satisfaction (HBS): & 0.522 & & 0.540 & & 0.435 & \\
\hline
\end{tabular}




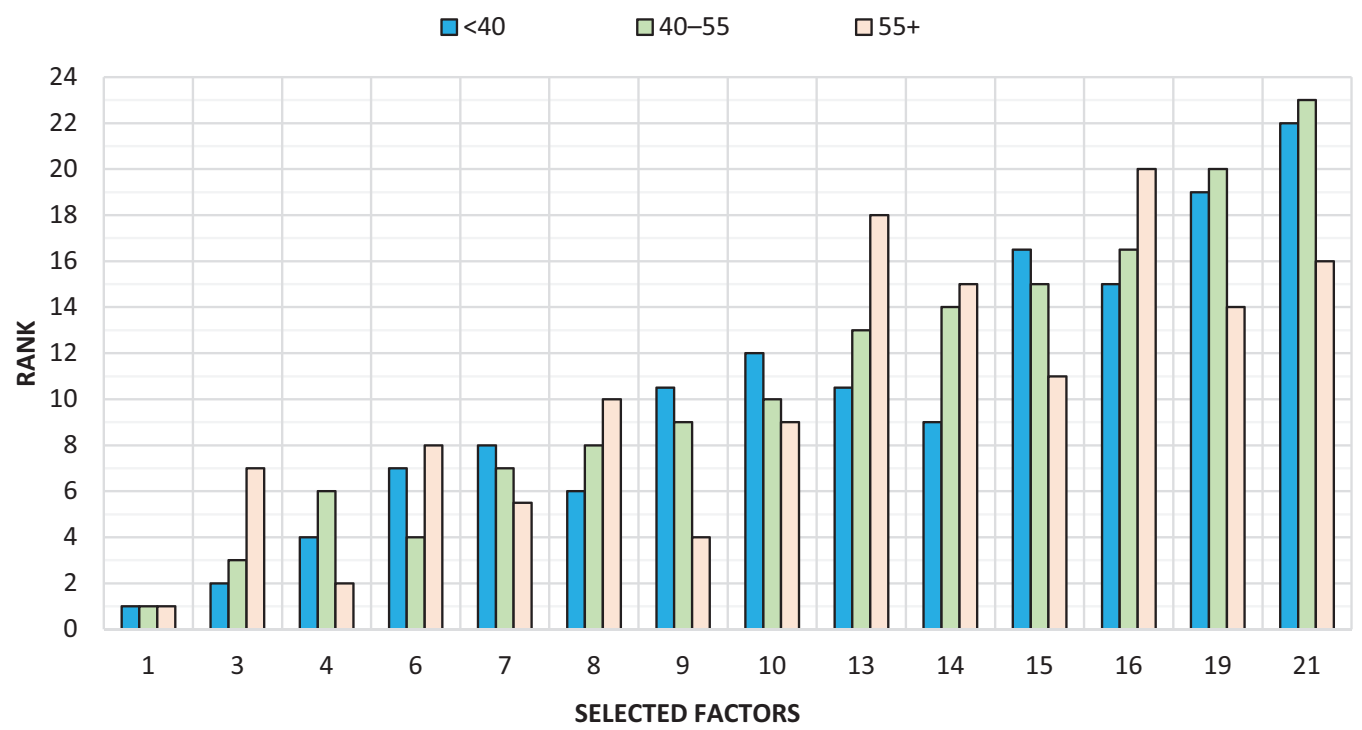

Figure 5. Rank variations by the age of the house-buyer

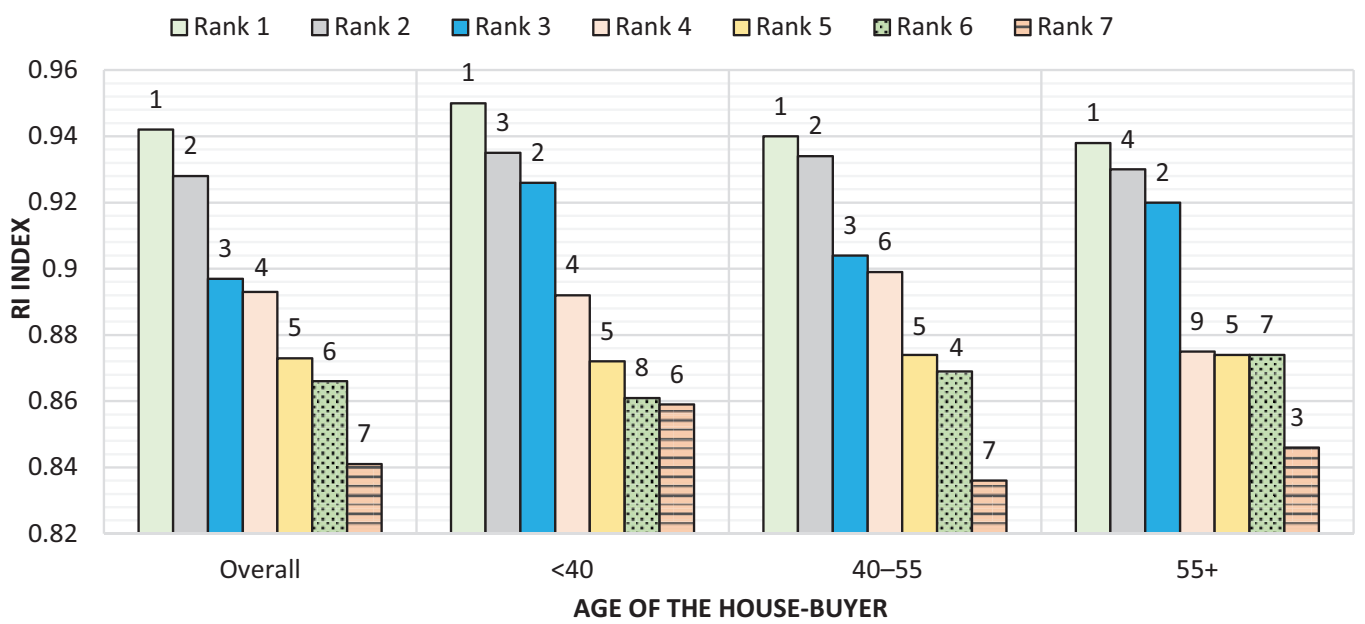

Figure 6. Seven highest ranked factors for each category of the age of the house-buyer

market' was assigned higher significance by the lower age groups. Although experience is traditionally considered to be very important in this market, it seems that it is perceived more important by higher age respondents. The findings also show that 'the size of indoor area' was perceived significantly more important by Group 2 respondents, while 'current stage of construction/time of delivery' was much more important for Group 1 respondents. These results indicate that young house-buyers in this market prefer to invest money in projects that are about to be completed in near future.

The House-Buyers' Satisfaction Scores presented in Table 5 show that buyers belonging to young and middle age groups are less dissatisfied than the buyers in the higher age group. Buyers belonging to different categories used different selection criteria and this resulted in significantly different residential satisfaction levels. The HBS scores of 0.540 for Group 2 and 0.522 for Group 1 are just below the neutral value of 0.544 . However, the HBS score found for higher age respondents, belonging to Group 3 was very low $(\mathrm{HBS}=0.435)$. This strikingly low score indicates a very significant dissatisfaction of the buyers in this category. In an effort to increase their market share, house-builders should analyze the needs of the potential clients under this category to gain competitive advantage.

For only the selected factors which had striking findings in the comparisons in this category, rank variations are displayed in Figure 5. Selected factors' ID numbers are displayed on the $\mathrm{X}$-axis, their respective ranks are shown on the $y$-axis while the different categories are displayed in different colours. Moreover, seven highest ranked factors for each category of the age of the house buyer are displayed in Figure 6. RI index for each factor is displayed on y-axis, ID numbers of the factors are displayed on top of the coloured columns while the different ranks from 1 to 7 are displayed in different colours. 


\section{Conclusions}

Numerous researchers have highlighted the importance of implementing customer-focused strategies in house-building sector. Moreover, other researchers have discussed the factors affecting post residential satisfaction. However, house selection and the resulting post residential satisfaction after the selection are two distinct but sequential stages of a complex and important process for people's lives considering the fact that buying a house is a lifetime investment. In an effort to uncover the main factors that characterize the two distinct and sequential stages of this process, namely house selection and post residential satisfaction, this study provided a comprehensive framework that had significant contribution to the research in this field. Unlike previous studies, this overall framework not only included one of the two sequential stages but both in a complete manner. While the study provided an enhanced insight into the relationship between the house-buyers' house selection criteria and the resulting postoccupancy overall satisfaction levels reached, it also differentiated among various types of client groups' behaviors in both house selection and the residential satisfaction stages. Various categories of house-buyers' significantly varying approaches and perceptions regarding house selection preferences and the resulting post residential satisfaction values were investigated within the developed overall framework.

Due to the intense competition in the market, the speculative house-builders have been focusing on offering a standard range of products, with an advantageous price and payment plan. However, the findings of this study clearly revealed that a significant dissatisfaction exists among the house-buyers in the market. Moreover, the findings confirmed that 'references about the house-builder' and hence positive word of mouth was perceived important by the buyers in house selection stage. It is a known fact that there is a strong correlation between clients' satisfaction and their willingness to recommend the firm to their friends or families. Therefore, this strikingly low overall satisfaction level indicates that there is room for improvement of house-builders in being more customer-focused in the highly competitive market. In order to outperform competitors, the builder firms should place high emphasis on the expectations of their existing customers, focus on strategies for achieving full satisfaction and aim to create future jobs with their positive recommendations.

Additionally, the satisfaction values vary significantly between the groups of respondents within the sector, categorized according to different control variables. In order to increase their share in the intensely competitive market, house-builders should follow a strategy of differing themselves from the competitors, focus and apply customer-focused strategies specifically for the categories of customers having very low satisfaction levels. If used properly by the house-builders in the market, these findings may actually be the market differentiator.

Further, it was found that the responses from housebuyers on their perceptions of a set of criteria contributing to their selection of the house-builder and the product vary very significantly among different categories of buyers.
This is a strong indication that the house-buyers belonging to different subgroups or categories have significantly different importance priority and hence behaviors in the product selection stage. This is actually an indication that it may not be possible to design and build a house, meeting the varying requirements of all of these categories of customers together. Therefore, these results suggest that the house-builder firms may benefit from market segmentation, within the house-building market. It will help the house-builders to understand the nature of the specific segment of the market in a better manner, focus on the house selection criteria of those within so that the capabilities and the strategies of the organization can be presented in ways best suited to take advantage of these. This is the area with a great potential for competitive advantage.

The findings of this study also confirmed the fact that both customization and the price/payment method were very important for the buyers in the house-building market. Although the findings about the importance of price/payment method was expected, it is also apparent that housebuyers do not prefer a standard range of products and definitely appreciate freedom of choice. Although clients usually prefer to select from alternatives, they will be less willing to prefer this if this option means a significant increase in price. Since more customization usually means increase in price, house-builders should focus on developing more flexible processes to be able to offer optimum customization, which can be determined only after detailed investigation about the customization preferences of the buyers in the studied market. Additionally, the emphasis assigned to customization varied between different categories of buyers. Therefore, these results suggest that there is a definite need for market segmentation before shaping strategies about customization in house-building market.

Considering the late delivery and the financial problems of the builders encountered in the house-building markets and also the fact that house-buyers may sign contracts with the house-builder firms before the product is completed, one would expect that factors related to the reliability of the house-builder firm itself would be assigned high significance levels. However, the findings surprisingly demonstrated that the factors related to the builder firm were assigned relatively lower emphasis, compared to the product related factors. This is an indication that builder firms may compete even with the more experienced competitors, if they focus their improvement efforts for making correct decisions about the design, customization and other important details of the house to meet the expectations of the potential buyers in the market.

The findings of this study suggest that various categories of buyers who assign emphasis on different criteria in their selection of the house, reach significantly different levels of post-occupancy residential satisfaction. Hence, an overall framework combining the selection preferences and the resulting satisfaction levels of house-buyers of different categories is developed. In an effort to determine the correct factors that should be considered during the product selection stage, these findings may provide a guide for the house-buyers to reach higher levels of post-occupancy residential satisfaction. 
In spite of the fact that this study was based on input provided by house buyers in North Cyprus construction market only, we believe that the approach, reasoning and the findings of this research are of good value to the house-builders and also buyers, not only in North Cyprus but also in similar markets throughout the world.

\section{Disclosure statement}

The author declares no competing financial, professional or personal interests.

\section{References}

Craig, D., \& Roy, R. (2004). Developing a customer-focused culture in the speculative house-building industry. Total Quality Management and Business Excellence, 5(1), 73-87. https://doi.org/10.1080/1478336032000149117

Dinc, P., Ozbilen, E., \& Bilir, M. B. (2014). A multi-dimensional scale for measuring residential satisfaction (rs) in mass housing projects. Indoor and Built Environment, 23(6), 864-880. https://doi.org/10.1177\%2F1420326X13484619

Egemen, M., \& Mohamed, A. N. (2006). Clients' needs, wants and expectations from contractors and approach to the concept of repetitive works in the Northern Cyprus construction market. Building and Environment, 41(5), 602-614. https://doi.org/10.1016/j.buildenv.2005.02.021

Fakere, A. A., Arayela, O., \& Folorunso, C. O. (2017). Nexus between the participation of residents in house design and level of residential satisfaction in Akure, Nigeria. Frontiers of Architectural Research, 6, 137-148. https://doi.org/10.1016/j.foar.2017.02.003

Fellows, R. (2014). Towards satisfying the client: optimizing, satisficing or disappointing? Engineering Project Organization Journal, 4(2-3), 89-106.

https://doi.org/10.1080/21573727.2013.873718

Fernandez, J. M. M., Gonzalez, C. P., Cabal, V. A., \& Balsera, J. V. (2016). Analysis of the quality control planning in residential construction projects in Spain. Revista de la Construccion, 15(2), 106-114. https://doi.org/10.4067/S0718-915X2016000200011

Gunduz, M., Nielsen, Y., \& Ozdemir, M. (2013). Quantification of delay factors using the relative importance index method for construction projects in Turkey. Journal of Management in Engineering, 29(2), 133-139.

https://doi.org/10.1061/(ASCE)ME.1943-5479.0000129

Hofman, E., Halman, J. I. M., \& Ion, R. A. (2006). Variation in housing design: identifying customer preferences. Housing Studies, 21(6), 929-943. https://doi.org/10.1080/02673030600917842

Jennings, P., \& Holt, G. D. (1998). Prequalification and multicriteria selection: a measure of contractors' opinions. Construction Management and Economics, 16(6), 651-660. https://doi.org/10.1080/014461998371944

Jiboye, A. D. (2012). Post-occupancy evaluation of residential satisfaction in Lagos-Nigeria: feedback for residential improvement. Frontiers of Architectural Research, 1(3), 236-243. https://doi.org/10.1016/j.foar.2012.08.001

Kometa, S. T., Olomolaiye, P. O., \& Harris, F. C. (1994). Attributes of UK construction clients influencing project consultants' performance. Construction Management and Economics, 12(5), 433-443. https://doi.org/10.1080/01446199400000053

Kotler, P., \& Keller, K. (2006). Marketing management (12th ed.). Prentice Hall.
Nahmens, I., \& Ikuma, L. H. (2009). Discovering the variables that influence new home-buyer service satisfaction. International Journal of Consumer Studies, 33(5), 581-590. https://doi.org/10.1111/j.1470-6431.2009.00801.x

Nguyen, A. T., Tran, T. Q., Vu, H. V., \& Luu, D. Q. (2018). Housing satisfaction and its correlates: a quantitative study among residents living in their own affordable apartments in urban Hanoi, Vietnam. International Journal of Urban Sustainable Development, 10(1), 79-91. https://doi.org/10.1080/19463138.2017.1398167

Nguyen, T. A., Tran, T. Q., Van, H. V., \& Luu, D. Q. (2019). Access to homebuyer credit and housing satisfaction among households buying affordable apartments in urban Vietnam. Cogent Economics \& Finance, 7(1), 1638112. https://doi.org/10.1080/23322039.2019.1638112

Nguyen, T. H., Berstein, S., McIntyre, C., \& Smith, G. R. (2008). Customer service management practices in the homebuilding industry. International Journal of Construction Education and Research, 4(1), 3-17.

https://doi.org/10.1080/15578770801943836

Othman, A. A. E. (2015). An international index for customer satisfaction in the construction industry. International Journal of Construction Management, 15(1), 33-58. https://doi.org/10.1080/15623599.2015.1012140

Ozaki, R. (2003). Customer-focused approaches to innovation in housebuilding. Construction Management and Economics, 21(6), 557-564. https://doi.org/10.1080/0144619032000134093

Riazi, M., \& Emami, A. (2018). Residential satisfaction in affordable housing: a mixed method study. Cities, 82, 1-9. https://doi.org/10.1016/j.cities.2018.04.013

Sambasivan, M., \& Soon, Y. W. (2007). Causes and effects of delays in Malaysian construction industry. International Journal of Project Management, 25, 517-526. https://doi.org/10.1016/j.ijproman.2006.11.007

Schoenwitz, M., Naim, M., \& Potter, A. (2012). The nature of choice in mass customized house building. Construction Management and Economics, 30(3), 203-219. https://doi.org/10.1080/01446193.2012.664277

Shash, A. (1993). Factors considered in tendering by top UK contractors. Construction Management and Economics, 11(2), 111-118. https://doi.org/10.1080/01446199300000004

State Planning Organization. (2018). Household labour statistics. North Cyprus.

Torbica, Z. M., \& Stroh, R. C. (2001). Customer satisfaction in home building. Journal of Construction Engineering and Management, 127(1), 82-86. https://doi.org/10.1061/(ASCE)0733-9364(2001)127:1(82)

Tran, T. Q., \& Van Vu, H. (2018). A microeconometric analysis of housing and life satisfaction among the Vietnamese elderly. Quality \& Quantity, 52(2), 849-867. https://doi.org/10.1007/s11135-017-0492-9

Wang, D., He, S., Webster, C., \& Zhang, X. (2019). Unravelling residential satisfaction and relocation intention in three urban neighborhood types in Guangzhou, China. Habitat International, 85, 53-62. https://doi.org/10.1016/j.habitatint.2019.01.004

Wang, D., \& Wang, F. (2016). Contributions of the usage and affective experience of the residential environment to residential satisfaction. Housing Studies, 31(1), 1-19. https://doi.org/10.1080/02673037.2015.1025372

Zang, F., Zhang, C., \& Hudson, J. (2018). Housing conditions and life satisfaction in urban China. Cities, 81, 35-44. https://doi.org/10.1016/j.cities.2018.03.012 